\title{
ESBOÇO DE UMA FENOMENOLOGIA DA CONSCIÊNCIA BRASILEIRA
}

\section{Outline of a phenomenology of Brazilian consciousness}

Leonardo Alves Vieira*

Resumo: Este artigo lida com o diálogo construído com base em um conjunto de três textos: 1) A Fenomenologia do espírito (1807) de Hegel (1770-1831), mais especificamente, os subcapítulos VI. C. a. A visão moral do mundo (Die moralische Weltanschauung), e VI. C. b. A dissimulação (Die Verstellung) do capítulo VI. O espírito certo de si mesmo. A moralidade (Der seiner selber gewisse Geist. Die Moralität); 2) o comentário (1972) a estes subcapítulos feitos por Lima Vaz (19212002) e 3) o conto de Guimarães Rosa (1908-1967) O recado do Morro (1956). Este conjunto aborda três temas: i) moralidade e natureza, ii) percepção da realidade tal como ilustrada pelas figuras da consciência e iii) a totalidade, racionalmente organizada, dessas figuras da consciência. Eles serão investigados pelos conceitos de a) moralidade e felicidade, b) figuras da consciência e c) silogismo dialético. $O$ resultado desse entrelaçamento conceitual é a interpretação de $O$ recado do morro de Rosa como uma leitura da cultura brasileira em suas diferentes figuras da consciência, desde sua manifestação mais baixa até sua forma mais avançada: um esboço da fenomenologia da consciência brasileira. Segundo esta leitura, a mensagem comunicada pelo morro, inicialmente captada por Gorgulho, obtém sua correta interpretação por seu destinatário, Pedro Orósio, com a ajuda da arte. Além disso, como uma obra de arte, o próprio texto de Rosa $O$ recado do morro, no amplo contexto da cultura brasileira, é uma espécie de metateoria de o que experiencia o destinatário da mensagem em seu processo de educação: acesso à verdade pela mediação da arte.

Palavras-chave: Palavras-chave: Hegel. Lima Vaz. Guimarães Rosa. Consciência brasileira.

\footnotetext{
* Professor do Departamento de Filosofia da Universidade Federal de Minas Gerais (UFMG). Artigo recebido em 26/02/2021 e aprovado para publicação em 28/02/2021.
} 
Abstract: This paper deals with a dialogue built on three texts: 1) Hegel's (17701831) Phenomenology of Mind (1807), more specifically, the subchapters VI. C. a. The Moral View of the World (Die moralische Weltanschauung), and VI. C. b. The Dissemblance (Die Verstellung) of the chapter VI. The Spirit Certain of Itself. Morality (Der seiner selber gewisse Geist. Die Moralität); 2) the commentary (1972) on these subchapters by Lima Vaz (1921-2002), and 3) Guimarães Rosa's (1908-1967) short story The Message of The Hill (1956). This set addresses three topics: i) morality and nature, ii) the perception of reality by different modes of consciousness, and iii) the rationally organized totality of these modes of consciousness. They will be investigated through the concepts of a) morality and happiness, b) modes of consciousness, and c) dialectical syllogism. The result of this conceptual intertwining is the interpretation of Guimarães Rosa's The Message of The Hill as a means to understand Brazilian culture in its different modes of consciousness, from its lowest to its most advanced form: an outline of the phenomenology of Brazilian consciousness. According to this reading, the message given by the hill, and initially received by Gorgulho, is correctly interpreted by its recipient, Pedro Orósio, with the help of art. In addition, as a work of art, the very text of The Message of The Hill by Rosa, in the broad context of Brazilian culture, is a kind of metatheory of what the recipient of the message experiences in his educational process, that is, access to the truth through the medium of art.

Keywords: Hegel. Lima Vaz. Guimarães Rosa. Brazilian consciouness.

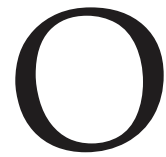

propósito desse artigo é articular um diálogo entre três textos: a) os subcapítulos VI. C. a. a visão moral do mundo (Die moralische Weltanschauung), e VI. C. b. A dissimulação (Die Verstellung) do capítulo VI. O espírito certo de si mesmo. A moralidade (Der seiner selber gewisse Geist. Die Moralität) da Fenomenologia do Espírito (FE, 1807) de Hegel $(1770-1831)^{1}$; b) o comentário a estes subcapítulos feito por Lima Vaz (CLV, 1921-2002)² e c) o conto de Guimarães Rosa (1908-1967), O re-

\footnotetext{
${ }^{1}$ As citações do texto original alemão e as da tradução para o português serão, respectivamente, feitas da seguinte maneira: $\mathrm{PhG}$, e número de página; $\mathrm{FE}$, número do parágrafo, número da página. O texto introdutório ao capítulo VII. A religião será citado para referir o silogismo dialético com suas figurações e figuras tendo em vista interpretar o conjunto das experiências da consciência. No entanto, o tema da religião não será objeto de estudo no artigo. HEGEL, G. W. F. Phänomenologie des Geistes. Neu hrsg. von Hans-Friedrich Wessels u. Heirinch Clairmont. Hamburg: Meiner, 1988. HEGEL, G. W. F. Phänomenologie des Geistes. Fenomenologia do Espírito. Tradução de Paulo Menezes com a colaboração de Karl-Heinz Efken e José Nogueira Machado. 2a. Edição. Petrópolis: Vozes, Bragança Paulistas, Universidade São Francisco, 2003. (Volume único).

${ }^{2}$ VAZ, H. L. Análise do texto da Fenomenologia do Espírito de G. W. F. HEGEL. A Moralidadade, 3a Parte da seção Espírito (Cap. VI). Trata-se de material oriundo de exposição oral feita por Vaz em disciplina ministrada no Departamento de Filosofia da Faculdade de Filosofia e Ciências Humanas da Universidade Federal de Minas Gerais no primeiro semestre de 1972. Inicialmente gravada em fitas cassetes, ela foi posteriormente desgravada e, finalmente,
} 
cado do morro $(R M)^{3}$. Os conceitos de 1) moralidade e felicidade, 2) figura e figurado e 3) silogismo dialético - os quais tratam de três conjuntos temáticos: i) a relação entre moralidade e natureza, razão e sensibilidade, mundo humano e mundo natural, terra e cosmo, ii) a percepção da realidade, tal como ela é interpretada pelas várias formas de consciência e iii) a totalidade racionalmente organizada das diferentes formas de manifestação da consciência - fazem a mediação entre os três textos. Com isso, então, de modo análogo ao que é exposto na FE de Hegel, pretendo expor os tipos de consciência presentes no contexto da cultura brasileira, tal como constatados em RM. Portanto, interpreto RM como um painel da consciência brasileira desde o seu patamar mais elementar até seu nível supremo, pelo menos tal como o texto rosiano nos deixa entrever, assim como analogamente, na FE, é exposto o movimento da consciência desde a certeza sensível ao saber absoluto.

Levo a cabo o acima proposto da seguinte maneira: primeiro, faço uma apresentação da FE tendo como fio orientador o conceito de figura da consciência (Gestalt des Bewußtseins), lançando mão tanto do texto introdutório (Einleitung) à FE quanto do texto introdutório ao capítulo VII. A religião, no qual é apresentada a figura da consciência no contexto do silogismo dialético organizador das experiências da consciência, mas também no qual é introduzido o conceito de figuração, perfazendo, assim, a distinção entre figura e figuração. Em um segundo momento, trato da figura da moralidade nas suas duas subformas: a visão moral do mundo e a dissimulação, que discutem formas não bem sucedidas de harmonizar moralidade e natureza, razão pura a priori e sensibilidade. As observações sobre o movimento dialético da consciência nesta figura serão feitas mediante referências ao comentário de Lima Vaz.

Evidentemente, a apresentação da FE que leva em conta apenas a figura da consciência, tal como é o caso aqui, deixa de lado vários outros temas que a introdução e mesmo o prefácio (Vorrede) analisam. Além disto, a interconexão dos conceitos no pensamento de Hegel impede isolar um determinado conceito, o qual, em virtude de sua própria constituição, se interliga com a marcha dialética do conjunto de conceitos. No entanto, o recorte proposto neste artigo é justificado, de um lado, pelas limitações materiais: o caráter de esboço do tema investigado e, por outro lado, pelas limitações formais: as exigências editoriais da própria estrutura do artigo. Apesar disto, o foco no conceito de figura e sua contextualização

transcrita em forma datilografada, totalizando setenta e três folhas datilografadas. O material encontra-se em fase de edição para posterior publicação. Doravante, o texto será citado como CLV, seguido do número da folha em que se encontra o texto referido.

${ }^{3}$ ROSA, J. G. O recado do morro, in: Rosa, J. G. Ficção completa, em dois volumes. Rio de Janeiro: Nova Aguiar, 1994. (Volume I, p. 615-66). As passagens de O recado do morro serão referidas como RM, seguidas do número de página das passagems citadas. 
no silogismo dialético nos permitem avançar pelo texto da FE para compreender suas linhas gerais e, ao mesmo tempo, colocá-lo em linha de diálogo com RM.

Depois disto, em um terceiro momento, entro na análise de RM sob a ótica de um referencial consciencial no qual diferentes formas de consciências são organizadas de acordo com seu maior ou menor grau de compreensão daquilo que se manifesta diante de cada uma delas no que diz respeito ao recado transmitido pelo morro. Para tanto, lanço mão do conceito de figurado para descrever o movimento das formas de consciência expostas em RM. Ele é construído como uma síntese entre o conceito de figura da FE e o termo figurado empregado em RM, de tal modo que ele possa traçar a especificidade do percurso da consciência em RM, levando em conta tanto a relação entre saber e verdade, herança do regime conceitual da FE, quanto a lógica dos figurados da consciência em RM, não mais redutível à logica do movimento da consciência na FE.

Por fim, de modo análogo ao movimento exposto pelo silogismo dialético da consciência na FE, apresento o silogismo dialético de RM. Por conseguinte, obtenho as condições para organizar as experiências da consciência em RM, alcançando, com isso, sua disposição ordenada segundo sua amplitude cognitiva perante a mensagem transmitida pelo morro da Garça.

Considero este texto como uma homenagem ao estudioso da filosofia hegeliana, o pensador mineiro, Lima Vaz. No entanto, a homenagem não consiste apenas em reproduzir seu estudo da filosofia hegeliana, no caso em questão, seu comentário aos textos do capítulo VI da FE aqui investigados, mas também e fundamentalmente levar adiante o "espírito" de sua leitura da obra hegeliana, a saber, sua intenção de ler a cultura brasileira com o auxílio de categorias filosóficas: no estudo aqui proposto, com a cooperação de conceitos retirados da FE e readaptados para uma leitura da cultura brasileira de acordo com os níveis conscienciais nela verificados por RM.

Portanto, traço as linhas gerais de uma fenomenologia da consciência brasileira, aguardando uma oportunidade mais favorável tanto para aprofundar os temas aqui expostos quanto para tratar de outros, relacionados ao objeto de estudo deste artigo, mas aqui não investigados.

\section{Figuras da consciência: apresentação através do texto da introdução (Einleitung) à FE e mediante o texto introdutório ao capítulo VII. A religião}

Gestalt é a palavra alemã que, via de regra, é traduzida como figura e é a mais frequentemente usada no texto alemão de introdução à FE. No entanto, esse texto também lança mão de uma outra palavra, a saber, figurações 
(Gestaltungen). Ela aparece no contexto em que se fala da série (Reihe) de figurações que a alma ou a consciência percorre ao longo do seu processo de formação (Bildung) em direção ao conhecimento de si mesma ou sua elevação ao status de espírito, como é o caso da alma, ou em direção à ciência, como é o caso da consciência. (FE 77, 74/PhG, 60). A série de figurações é equivalente a "a sequência completa das figuras da consciência" (die ganze Folge der Gestalten des Bewußtseins, FE 87, 81/PhG 67), pois, em ambos os casos, a saber, tanto na série das figurações quanto na sequência das figuras, tem lugar a necessidade (Notwendigkeit, FE 87, 81/PhG 67) das estações percorridas pela consciência. No contexto da introdução à $\mathrm{FE}$, portanto, figurações e figuras parecem ser termos sinônimos.

No último parágrafo do texto de introdução à $\mathrm{FE}$, aparece, de forma mais nítida do que em parágrafos anteriores, a definição de figuras da consciência: "os momentos do todo" (Die Momente des Ganzen, FE 89, 82/PhG, 68). Com efeito, os momentos do todo são os momentos da experiência (Erfahrung) que a consciência realiza nela mesma tanto em seu saber quanto em sua verdade, de tal modo que cada figura articula, de forma peculiar, a relação entre saber, "ser de algo para uma consciência", e verdade, "ser em si" (FE, 86, 80/PhG, 66). Ora, o ser em si da verdade se mostrará, ao longo das experiências da consciência, como um ser em si para o saber. Com isso, então, o questionamento à verdade e o surgimento de "o novo objeto verdadeiro" (der neue wahre Gegenstand, FE, 86, 80/PhG, 66) implicam também um questionamento ao saber e, consequentemente, o surgimento de um novo saber correspondente ao novo objeto verdadeiro, de tal forma que a crítica a ambos engendrará necessariamente uma nova figura da consciência, a saber, uma nova relação entre saber e verdade. Saber e verdade constituem, pois, o que Hegel chama, de um modo geral, consciência. Os momentos do todo são, portanto, formas determinadas de articular saber e verdade em um movimento de tal ordem que é exercida uma contínua crítica ao saber e à verdade que constituem cada figura da consciência. Consequentemente, erros e deficiências são inerentes a cada figura da consciência, os quais, no entanto - e isto é o lado positivo de erros e deficiências -, impelem todas as figuras à última figura, o saber absoluto, capaz de compreender as relações que as entretecem e interligam em um todo coerente e sistematizado.

Assim, por exemplo, o saber e a verdade absolutamente imediatos da certeza sensível, a figura inicial da experiência da consciência, são questionados e jogados por terra em favor de um novo saber e de uma nova verdade, ambos agora imediatos e mediatizados, que constituem a figura da percepção. Assim também é o caso do espírito certo de si mesmo da moralidade em que a verdade é posta pelo saber no puro pensar, o qual, então, é o critério do agir moral. Como veremos mais adiante, o grande desafio do espírito certo de si mesmo será harmonizar esse critério com o mundo da natureza, regido por um outro e diferente critério de ação. 
Feita essa apresentação bastante sucinta do que é a figura da consciência a partir do texto de introdução à $\mathrm{FE}$, tendo em vista a investigação do tema proposto, resta tratar de um outro texto importante para entender o papel desempenhado pelas figuras da consciência ao longo da FE: o texto introdutório ao capítulo VII. A religião.

Esse texto trata do silogismo dialético que exibe a estrutura da FE em suas grandes articulações. Nele, as figuras da consciência ocupam a posição da singularidade e articulam, de maneira mais evidenciada do que os momentos da universalidade e particularidade, a relação entre o lógico e o tempo. Eis, então, o silogismo dialético da FE exposto em termos de universalidade, particularidade e singularidade:

Universalidade: Espírito como tal ou universal;

Particularidade (figurações): consciência, consciência de si, razão, espírito, religião ;

Singularidade (figuras): figuras da consciência (por exemplo: certeza sensível e percepção no âmbito da figuração consciência; a moralidade na esfera da figuração espírito).

"Pois o espírito desce, a partir de sua universalidade através da determinação, para a singularidade. A determinação ou o meio-termo são consciência, consciência de si, etc. No entanto, as figuras destes momentos constituem a singularidade. Essas apresentam, portanto, o espírito em sua singularidade ou efetividade e se diferenciam no tempo (FE, 679, 461)"

Portanto, em suas linhas gerais, o espírito desce à singularidade e, portanto, ao tempo pela mediação do que Hegel aqui chama de determinação ou meio-termo, mas, em termos da lógica dialética hegeliana, é chamado de particularidade. Aqui Hegel faz uma distinção sutil entre Gestaltungen, figurações, e Gestalten, figuras (ainda indiscriminadas no texto introdutório à $\mathrm{FE}$ ), pois as primeiras expressam os momentos expressos na particularidade (determinação ou meio-termo), ao passo que as segundas exprimem a singularidade.

Com isso, então, as figuras da consciência encarnam, no tempo, o espírito universal, em seu desdobramento lógico-dialético através da universali-

\footnotetext{
4 "Os momentos (...) são a consciência, a consciência de si, a razão e o espírito (...) O espírito como tal contém as figurações prévias nas determinações universais, nos momentos recentemente citados" (FE, 679,461). Die Momente (...) sind das Bewußtsein, das Selbstbewußtsein, die Vernunft und der Geist (...) der Geist als solcher enthält die bisherigen Gestaltungen in den allgemeinen Bestimmungen, den soeben genannten Momenten (PhG, 446).

${ }^{5}$ Denn der Geist steigt aus seiner Allgemeinheit durch die Bestimmung zur Einzelnheit herab. Die Bestimmung oder Mitte ist Bewußtsein, Selbstbewußtsein usf. Die Einzelnheit aber machen die Gestalten dieser Momente aus. Diese stellen daher den Geist in seiner Einzelnheit oder Wirklichkeit dar und unterscheiden sich in der Zeit (PhG, 446).
} 
dade e da, particularidade. Assim é o caso com a figura da moralidade que encarna a moralidade kantiana do espírito pós Revolução Francesa, o qual, agora, assevera que o critério da moralidade é posto por ele mesmo, sem ter que buscá-lo em Deus ou na natureza, como em figuras anteriores do espírito, enquanto este é entendido como meio-termo ou figuração do espírito universal.

Em resumo, a figura da consciência é a relação entre saber e verdade, tal como ela se encontra diferenciada no tempo e, ao mesmo tempo, assumida e suprassumida na racionalidade imanente ao desenvolvimento do espírito aqui exposta em termos de lógica dialética. Com efeito, "os momentos do todo" relatados no último parágrafo do texto introdutório à FE apresentam de forma mais clara o que eles são: por um lado, eles representam momentos do todo do Espírito universal, como já era evidenciado no texto introdutório, mas também, por outro lado e de forma mais detalhada, também expressam a diferenciação temporal de cada particularidade determinada ou figuração do espírito universal. De forma mais próxima ao nosso objeto de investigação, a moralidade é a última das figuras da figuração espírito do espírito universal. À figura da moralidade é agora dedicada nossa atenção.

\section{A figura da moralidade}

Ao comentar a figura da moralidade e sua visão moral do mundo (moralische Weltanschauung), Vaz a considera como consciência do dever, "porque ela é o saber da liberdade, pois neste saber ela é absolutamente livre, porque sabe a sua liberdade" $(\mathrm{CLV}, \mathrm{fl}-2)^{6}$. O espírito é livre e está certo de si mesmo, porque ele é capaz de justificar e, assim, legitimar a sua liberdade. E ele é livre porque sua liberdade está ancorada no puro pensar que põe a liberdade, de forma incondicionada, como ato desse puro pensar não mais fundamentado na natureza ou em Deus. Com isso, então, é posto também o dever ser (das Sollen), entendido como um obrigar-se a efetivar na realidade do mundo aquilo que foi determinado pelo puro pensar como ato incondicional da liberdade. Portanto, o indivíduo cumpre o dever somente na medida em que ele o faz livremente. Consequentemente, o dever não pode ser imposto de fora ao indivíduo, como se ele fosse resultado de heteronomia, mas ato de sua autonomia incondicional.

Feita essa observação introdutória sobre a nota distintiva da moralidade, passemos agora ao problema enfrentado pelo agente moral, pois ele se

\footnotetext{
${ }^{6}$ Es [das Bewußtsein] ist absolut frei, darin daß es seine Freiheit weiß, und eben dies Wissen seiner Freiheit ist seine Substanz und Zweck und einziger Inhalt (PhG 395); Ela [a consciência] é absolutamente livre nisto: que ela sabe sua liberdade, e justamente este saber de sua liberdade é sua substância, fim e único conteúdo" (FE 598, 411).
} 
encontra diante do desafio de harmonizar o critério do agir moral determinado pelo puro pensar, o imperativo categórico na conceituação de Kant, com sua natureza sensível, empírica e física, enfim, o mundo da natureza. Enquanto, do ponto de vista do saber da liberdade, o dever puro posto por este saber é o essencial, pois aqui o agente moral pratica sua ação orientado pela lei moral que põe a vontade do Nós como critério diretor da ação, a ação governada pela motivação oriunda por sua natureza sensível tem a marca de uma ação egocentrada, na qual o agente busca obter seu objeto de prazer, segundo a lógica do amor de si (Selbsliebe) ${ }^{7}$. Trata-se, portanto, de uma ação guiada pela ideia de felicidade, na qual os interesses privados do indivíduo se sobrepõem à vontade coletiva.

Portanto, os dois tipos de ação estão norteados por critérios completamente heterogêneos, sem que haja vislumbre de um elemento mediador, ínsito ao próprio agente moral, para harmonizar moralidade, como causa, e felicidade, como efeito, a saber, efetuar o sumo Bem (das höchste Gut) ${ }^{8}$. Por conseguinte, o postulado da existência de Deus torna-se inarredável tendo em vista pensar a efetuação do sumo Bem, a qual é o dever posto pelo saber da liberdade, já que o ser humano, em virtude de suas próprias forças, somente leva a cabo o tornar-se digno da felicidade mediante seus atos morais, esperando de Deus, o distribuidor (Austeiler) ${ }^{9}$ da felicidade, a concessão necessária da felicidade a quem possui o mérito moral de recebê-la.

A figura da moralidade, tal como descrita por Hegel, apresentará as tentativas fracassadas de realizar ou efetivar (verwirklichen) - tal é o termo empregado por Hegel ao longo dos subcapítulos a visão moral do mundo e a dissimulação ao invés de bewirken, usado por Kant, via de rega, - a tão pretendida harmonia. A razão para uma tal desarmonia encontra-se no fato de que o ponto de partida é uma cisão original, de tal forma que não é mais possível harmonizar o que por princípio não é mais harmonizável. Em virtude da heterogeneidade que separa a lei moral e o princípio organizador das ações voltadas à obtenção da felicidade, assistimos, então, nós leitores e leitoras da experiência da consciência na figura da moralidade, várias tentativas malogradas para efetivar a verdade da moralidade: efetivar o sumo Bem ${ }^{10}$. Essas tentativas desfiguram gradualmente - ao longo dos três subcapítulos a visão moral do mundo, a dissimulação e a boa consciência: a bela alma, o mal e seu perdão - a figura da moralidade, a tal ponto que o pensamento puro do indivíduo moral deixa de ser aquele

\footnotetext{
${ }^{7}$ KANT, I. Kritik der praktischen Vernunft. Darmstadt: WBG, 1983, A 40.

${ }^{8}$ A efetuação do sumo Bem no mundo é o objeto necessário de uma vontade determinável pela lei moral; Die Bewirkung des höchsten Guts in der Welt ist das notwendige Objekt des durchs moralische Gesetz bestimmbaren Willens; KANT, I. Kritik der praktischen Vernunft. Darmstadt: WBG, 1983, A 219.

${ }^{9}$ KANT, I. Kritik der praktischen Vernunft. Darmstadt: WBG, 1983, A 232.

${ }^{10}$ Não é meu propósito avaliar a crítica de Hegel à ideia de sumo Bem em Kant, mas apenas apresentar essa própria crítica sem qualificar seus possíveis méritos ou deméritos.
} 
que põe a lei moral em favor de sua transferência para Deus, entendido como legislador divino. Ele pratica, com isso, uma espécie de suicídio moral ou uma autoimplosão moral de si mesmo: a figura da moralidade se des-figura, - não pode mais manter de pé seu saber e sua verdade: a lei moral posta pelo saber da liberdade - e, por conseguinte, cede lugar a outra figura da experiência da consciência: a boa consciência (Gewissen).

Não é minha intenção expor detalhadamente todas as tentativas fracassadas para harmonizar moralidade e felicidade e nem mesmo isto seria possível fazer nos limites deste artigo. Isto já o fiz em outras oportunidades ${ }^{11}$. O que vou fazer, portanto, é lançar mão de comentários feitos por Vaz sobre uma tentativa fracassada da consciência de si moral para harmonizar moralidade e felicidade, porque ele nos ajudará a melhor compreender o que se passa em RM com aquele figurado que gradualmente compreende o recado do morro: Pedro Orósio. Trata-se, pois, do esforço de conciliar razão (Vernunft) e sensibilidade (Sinnlichkeit).

Depois de investigar os problemas relacionados com as tentativas de reconciliar moralidade e a natureza externa, Hegel passa a analisar o esforço da consciência moral para compatibilizar a moralidade com a natureza interna. De um lado, há a razão pura a priori que determina a lei moral e, de outro, há as inclinações (Neigungen) e os impulsos (Triebe), os quais não só são independentes, mas também contrários à lei moral. Como bem lembra Vaz (Vaz fl-37), se, no caso anterior, naquele da relação da moralidade com a natureza externa, a natureza era indiferente à moralidade, agora, as inclinações e impulsos se mostram como levando adiante uma dinâmica antagônica àquilo que é determinado pela razão prática pura: trata-se do antimoral como aquilo que se opõe à moralidade.

Por conseguinte, o propósito da consciência de si moral consiste em pôr seu próprio fim puro, não mais condicionado pelos fins das inclinações e impulsos: estes últimos identificados por Vaz, em uma linguagem mais próxima a nossa compreensão atual, com o psiquismo humano (CLV, fl-31). O fim puro, por sua vez, não pode mais tolerar os fins da sensibilidade e elimina-os ${ }^{12}$, já que os últimos estão postos por critérios de ação egocentra-

${ }^{11}$ VIEIRA, L. A.. Kant e Hegel sobre moralidade e felicidade. In: BOMBASSARO, L. C. \& DALBOSCO, C. A. \& HERMANN, N.. (Org.). Percursos hermenêuticos e políticos: Homenagem a Hans-Georg Flickinger. 1a.ed.Porto Alegre: EDIPUCRS, 2014, v. 1, p. 289-315; 7; VIEIRA, L. A.. A visão moral do mundo. In: VIEIRA, Leonardo A.; SILVA, Manuel M. (Org.). Interpretações da Fenomenologia do Espírito de Hegel. 1ed.São Paulo: Loyola, 2014, v. 1, p. 347-355; VIEIRA, L. A.. A dissimulação. In: VIEIRA, Leonardo A.; SILVA, Manuel M. (Org.). Interpretações da Fenomenologia do Espírito de Hegel. 1ed.Loyola: São Paulo, 2014, v. 1, p. 355-367.

12 "A consciência de si moral estabelece seu fim como puro, como independente de suas inclinações e impulsos, de tal modo que ele eliminou dentro de si os fins da sensibilidade (FE, 622, 424)"; "Das moralische Selbstbewußtsein stellt seinen Zweck als rein, als von Neigungen und Trieben unabhängig auf, so da $\beta$ er die Zwecke der Sinnlichkeit in sich vertilgt hat"(PhG, 408). 
dos. Resta, então, estabelecido o conflito de dois tipos de fim: o fim estabelecido pela razão prática pura e o fim orientado pela sensibilidade. Eles consolidam, portanto, linhas de ação governadas por critérios totalmente heterogêneos e, em virtude disso mesmo, inevitavelmente irreconciliáveis. No entanto, o fim puro posto pela razão pura incondicionada só pode tornar-se realidade efetiva (Wirklichkeit) pela mediação da sensibilidade, uma vez que justamente esta última é aquilo que está presente e existe naquela realidade. Como, então, realizar efetivamente no mundo o fim puro lançando mão de uma mediação que nega justamente aquilo que deve ser posto na realidade efetiva do mundo? Aqui, mais uma vez, mostra-se a dissimulação (Verstellung), já que ela já apareceu antes e aparecerá em outras oportunidades da experiência da consciência de si moral.

Inviabilizada de levar a cabo o que ela pretende, a consciência de si moral não pode simplesmente eliminar ou aniquilar sua dimensão ligada à natureza. Uma tal eliminação ou aniquilação significaria destruir a própria consciência de si moral, pois ela é uma mediação entre razão e sensibilidade. Diante dessa impossibilidade, ela engendra manobras dissimuladoras para tentar articulá-las.

A primeira é a repressão. Mas por que a repressão é uma manobra dissimuladora? Em primeiro lugar, a repressão à sensibilidade é melhor do que sua eliminação, porque aquela mantém os dois elementos constitutivos da consciência de si moral, certa de si mesma, embora eles sejam discriminatoriamente avaliados: a razão é o essencial, ao passo que a sensibilidade é o inessencial. Em segundo lugar, a repressão é o tipo de ação que tanto mantém a sensibilidade quanto a razão, mas de tal forma que esta não é incomodada ou perturbada por aquela, pelo menos segundo a perspectiva da atitude repressora.

Contudo, a repressão não consegue impedir ou obstaculizar a dinâmica dos impulsos e inclinações. Eles ficam à espreita ou rondam sorrateiramente o mundo da consciência de si moral e, por isso mesmo, inviabilizam a passagem do fim puro e incondicionado para a realidade efetiva do mundo. Por isso mesmo, "eles (inclinações e impulsos) não devem ser reprimidos, mas ser somente conformes à razão"13 (FE, 622, 424). Com efeito, após o fracasso da estratégia da repressão, entra em cena a proposta da conformidade entre razão e sensibilidade. Todavia, não menos problemático é este tipo de manobra dissimuladora.

Ele não é menos problemático, porque a manobra dissimuladora da conformidade rebaixa a razão ao nível da sensibilidade. A razão prática pura, porém, é a faculdade superior de apetição, ao passo que a sensibilidade é

13 "sie (Neigungen und Triebe) sollen auch nicht unterdrückt, sondern der Vernunft nur gemäß sein" (PhG, 409). 
a faculdade inferior de apetição ${ }^{14}$. Ela é superior, justamente porque tanto põe o Nós acima do Eu, o imperativo categórico em posição mais elevada do que a do amor de si, quanto vislumbra o sumo Bem (harmonia entre moralidade e felicidade), incapaz de ser contemplado por uma faculdade, tal como a sensibilidade, que não se eleva ao plano da razão prática pura e incondicionada. Consequentemente, a dissimulação chamada conformidade significa autoimplosão moral da consciência de si moral, certa si mesma. O que é racional, a saber, o dever puro posto pela razão prática pura e incondicionada, não é realidade efetiva no mundo, é somente um postulado, algo pensado, algo que deve ser, mas não é efetivado no mundo. Contudo, o que é efetivo no mundo, isto é, a desarmonia entre moralidade e felicidade, não é o racional. Por conseguinte, longe estamos de "o que é racional é efetivo, o que é efetivo é racional"15.

Diante desse fracasso, a consciência de si moral projeta para o futuro indeterminado e nebuloso (a terceira manobra dissimuladora, depois da repressão e da conformidade) o que ela não consegue alcançar aqui e agora na realidade efetiva do mundo. A moralidade deixa de ser a luta (Kampf, PhG, 409; FE 622, $425)^{16} \mathrm{com}$ a sensibilidade, enquanto esta tenta ser o elemento determinante da vontade. Mas alcançada a tão pretendida harmonia no futuro indeterminado e nebuloso, a moralidade, enquanto saber da liberdade expresso pela razão prática pura ou pelo pensar puro, se desintegra, pois não há mais oposição entre moralidade e sensibilidade: "sob pretexto do avanço da moralidade como um progresso, nós estaremos, cada vez mais, satisfazendo os fins da natureza e não os fins específicos da própria moralidade" (CLV, fl-32).

Além de a harmonia não ser efetivada no presente, aqui e agora, pois a efetivação do dever puro é a liberdade efetivando-se na realidade do mundo, o deslocamento da harmonia entre moralidade e felicidade para um futuro indeterminado e nebuloso destrói a própria noção de moralidade. Eis o pior dos mundos: o racional não está efetivado no presente e nem mesmo o será no futuro!

Como o progresso em direção ao futuro harmonioso entre moralidade e felicidade já é um estado de não moralidade [assim como o é também o fim a ser alcançado por aquele progresso], porque o racional não é efetivo, e o efetivo não é racional, a felicidade deixa de ser aquilo que é obtido através do mérito moral para ser feliz: exigência inarredável para a efetuação do sumo Bem. Se o racional não é praticado, a saber, se o dever puro não é efetivado no mundo, a felicidade existente no mundo flutua, por assim dizer, no espaço das ações libertas do poder atrativo gravitacional do impe-

\footnotetext{
${ }^{14}$ Unteres Begehrungsvermögen, oberes Begehrungsvermögen: KANT, I. Kritik der praktischen Vernunft. Darmstadt: WBG, 1983, A 41.

15 "was vernünftig ist, das ist wirklich; und was wirklich ist, das ist vernünftig". Hegel, G. W. F. Grundlinien der Philosophie des Rechts oder Naturrecht und Staatswissenschaft im Grundrisse. Frankfurt: Suhrkamp, 1973. v.7, p. 24. (Werke, 7; Theorie-Werkausgabe).

${ }^{16}$ KANT, I. Kritik der praktischen Vernunft. Darmstadt: WBG, 1983, A 151.
} 
rativo categórico. Consequentemente, a dissimulação moral aqui praticada engendra um descolamento da felicidade em relação à moralidade, de tal modo que ela é obtida mediante "acaso e arbítrio" (Zufall und Willkür, PhG, 410/FE 624, 426), enquanto o sumo Bem, tal como determinado pela razão prática pura, deve ser resultado tanto da síntese pura a priori entre moralidade, como causa, e felicidade, como efeito, e, portanto, necessária [e, com isso, não casual] quanto de uma vontade regida pelo imperativo categórico [e não mediante arbítrio].

A felicidade, com efeito, oscila, de um lado, entre sua ligação necessária com a moralidade, de acordo com a lógica do sumo Bem, e seu afastamento da moralidade, enquanto a felicidade ou é fruto do acaso ou é resultado do arbítrio regido pela sensibilidade ou pelo psiquismo humano, de outro. Aqui Vaz vê uma aproximação com aquilo que mais tarde Nietzsche (1844 - 1900) chamará moral do ressentimento. Mas ressalto que não é meu interesse avaliar se tal aproximação é pertinente ou não. Limito-me a relatar tal aproximação e a razão de ela ser feita.

Ora, como a felicidade pode ser encarada como efeito do acaso e do árbitro, a atribuição de felicidade merecida ou imerecida a um indivíduo não pode mais estar calcada no imperativo categórico. Qual é, então, o critério usado quando a um determinado indivíduo é atribuída uma felicidade imerecida? Se a lei moral objetiva não pode mais ser invocada para ser esse critério e se ela, a felicidade, é fruto do acaso, resta, então, um critério meramente subjetivo e arbitrário: a inveja. Escondida debaixo do manto da moralidade, a inveja decide arbitrariamente, a saber, por meio de uma subjetividade contingente, quem imerecidamente é feliz.

No entanto, a atribuição de felicidade imerecida a um determinado indivíduo revela a hipocrisia de quem a assim julga. Neste ponto, já resvalamos na figura da boa consciência (Gewissen), a qual, porém, não será objeto de estudo neste artigo, já que o critério moral perde sua objetividade, até então ancorada no imperativo categórico, e se rebaixa ao arbítrio de cada indivíduo.

Vemos, no outro, a felicidade obtida sem mérito moral, portanto, uma "felicidade imoral", porque o outro é um indivíduo fraco incapaz de realizar na efetividade do mundo o dever puro ao mesclar seus interesses privados, sua busca de prazer, como elemento determinante da vontade, na consecução da lei moral. Mas esse severo julgamento moral expressa também o ressentimento do seu formulador, pois ele também não consegue efetivar no mundo o dever puro, pois também seus interesses privados não puderam ser negligenciados. Com isso, então, ele projeta, de forma ressentida, no outro o que ele mesmo não faz. $\mathrm{O}$ moralista, com efeito, não pratica o que ele mesmo prega e, a fim de afastar de si este conflito, ele lança no outro o que ele mesmo não faz, além de querer possuir a felicidade que o outro, a seus olhos, imerecidamente possui e que ele deve merecidamente possuir. $\mathrm{O}$ discurso moralista não deixa de transparecer um mecanismo de defesa para encobrir a fraqueza moral do formulador 
de tal discurso: a moral dos moralmente fracos, porque não praticam o dever puro, elevada à categoria de moralidade por excelência, mas uma moralidade somente discursiva e nunca praticada.

Um outro tópico também ressaltado por Vaz diz respeito ao papel da repressão à sensibilidade relatado acima e à antecipação de um tema a ser posteriormente investigado por Freud (1856 - 1939). Trata-se do tema da relação da moral burguesa com o inconsciente: a moral da decência busca estabelecer a harmonia entre os mundos externo e interno (sensibilidade) com a moralidade. Obviamente, o simples uso da palavra Trieb por parte de Hegel para descrever o que se passa na sensibilidade reprimida não pode ser tomado como um uso da mesma nos sentidos atribuídos a ela por Freud ${ }^{17}$. O que é ressaltado por Vaz em seu comentário é o fato de que o regime do inconsciente tem os seus fins próprios e se encontra na esfera daquilo que é tematizado na FE como sensibilidade e é oriundo das reflexões kantianas sobre a questão moral. Portanto, trata-se aqui do difícil ajuste entre razão e sensibilidade agora pensadas como integração harmônica entre 1) a realidade efetiva do mundo, 2) a sensibilidade, representada pelo corpo somático individual e apresentada na forma de pulsões/impulsos (Triebe) do inconsciente, e 3) a razão, exposta como a moral burguesa da decência.

Enfim, Vaz considera as manobras dissimuladoras da consciência moral certa de si mesma como "uma análise genial da moral burguesa" (CLV, fl-33), bem como elas são, de certo modo, ao seu ver, uma antecipação de temáticas posteriormente refletidas por Freud, Nietzsche (o inconsciente e a moral do ressentimento) e também expressas em obras literárias de autores tais como Balzac (1799-1850), Stendhal (1783-1842) e Flaubert (1821-1880).

Ao fim e ao cabo, portanto, não há moralidade efetivada no mundo, como pretendia o espírito certo de si mesmo, mas há tentativas dissimuladas para justificar e legitimar o que não é justificável e legitimável: a não efetivação da moralidade.

\section{O Recado do Morro: contexto literário e filosófico}

A novela ${ }^{18}$ ou o conto ${ }^{19} \mathrm{O}$ Recado do Morro veio à luz originalmente na coletânea Corpo de Baile, publicada em dois volumes em 1956. No entanto, a partir da terceira edição em 1964, orientada pelo próprio Guimarães Rosa,

\footnotetext{
${ }^{17}$ GOMES. G. Os Dois Conceitos Freudianos de Trieb, in: Psicologia: Teoria e Pesquisa. Set-Dez 2001, Vol. 17 n. 3, pp. 249-255.

${ }^{18}$ ALVES, A. C. T. A viagem em o recado do morro: construção de espaços e identidades, in: Estação Literária, Londrina, Volume 10B, p. 20-32, jan. 2013, p. 20.

${ }^{19}$ ROSA, G. No Urubuquaquá, no Pinhém. 9. Ed. Rio de Janeiro: Nova Fronteira, 2001. (Edição eletrônica).
} 
ela foi dividida em três livros: Manuelzão e Miguilim, No Urubuquaquá, no Pinhém e Noites do Sertão. RM foi então publicado em No Urubuquaquá, no Pinhém, com outro conto Caras-de-Bronze e o romance A estória de Lélio e Lina, segundo a classificação dos gêneros literários em No Urubuquaquá, no Pinhém em sua nona edição.

De antemão, devo deixar claro que meu viés interpretativo de RM é predominantemente filosófico. Digo predominante filosófico, já que uma divisão tão nítida entre o filosófico e o literário é inviável em um texto como $\mathrm{RM}^{20}$. Este viés filosófico está configurado mediante duas ideias reitoras: 1) a primeira diz respeito ao sertão como um "mito da consciência brasileira" ${ }^{21}$, ao passo que a 2) segunda expressa os limites da razão discursiva, "a megera cartesiana" 22 .

Ad 1): o sertão como mito da consciência brasileira.

Em diálogo com Günter Lorenz, Rosa assente com a proposta daquele para iniciar a conversa: um início convencional, a saber, biográfico ${ }^{23}$. A convencionalidade aludida por Lorenz não é tão convencional assim, já que o ponto de partida biográfico do diálogo não é mero acidente, mas toca no elemento substancial, a saber, no quadro interpretativo com o qual Rosa compreende tanto sua vida privada quanto sua obra literária.

Concordando com a qualificação "homem do sertão" ${ }^{24}$ dada a ele por Lorenz, Rosa avança o diálogo ao afirmar que ao "conversar sobre este homem, já estão tocados no fundo os outros pontos" 25 que ainda serão objeto do diálogo, mas que ali, no "homem do sertão", se encontra o núcleo irradiador capaz de iluminar todos outros tópicos do diálogo: "ele está presente como ponto de partida mais do que qualquer outra coisa" ${ }^{26}$.

\footnotetext{
${ }^{20}$ A literatura interpretativa sobre a obra de Rosa é imensa, e não é meu interesse e nem haveria condições no espaço desse artigo de fazer sua revisão crítica. Sobre aquela literatura vide o website JOÃO GUIMARÃES ROSA. Banco de Dados Bibliográfico (https://www. usp.br/bibliografia/index.php?s=grosa) e Rosa, J. G. Ficção completa, em dois volumes. Rio de Janeiro: Nova Aguiar, 1994, p. 183-194, (Volume I)

${ }^{21}$ LORENZ, G. Diálogo com Guimarães Rosa, in: Rosa, J. G. Ficção completa, em dois volumes. Rio de Janeiro: Nova Aguiar, 1994, p. 30, (Volume I); sobre RM como uma "alegoria do Brasil", ALVES, A. C. T. A viagem em o recado do morro: construção de espaços e identidades, in: Estação Literária, Londrina, Volume 10B, p. 20-32, jan. 2013, p. 21.

${ }^{22}$ ALVES, A. C. T. A viagem em o recado do morro: construção de espaços e identidades, in: Estação Literária, Londrina, Volume 10B, jan. 2013, p. 21.

${ }^{23}$ LORENZ, G. Diálogo com Guimarães Rosa, in: Rosa, J. G. Ficção completa, em dois volumes. Rio de Janeiro: Nova Aguiar, 1994, p. 30, (Volume I).

${ }^{24}$ LORENZ, G. Diálogo com Guimarães Rosa, in: Rosa, J. G. Ficção completa, em dois volumes. Rio de Janeiro: Nova Aguiar, 1994, p. 30, (Volume I).

${ }^{25}$ LORENZ, G. Diálogo com Guimarães Rosa, in: Rosa, J. G. Ficção completa, em dois volumes. Rio de Janeiro: Nova Aguiar, 1994, p. 30, (Volume I).

${ }^{26}$ LORENZ, G. Diálogo com Guimarães Rosa, in: Rosa, J. G. Ficção completa, em dois volumes. Rio de Janeiro: Nova Aguiar, 1994, p. 30, (Volume I).
} 
Lorenz fixa, então, o "homem do sertão" como ponto de partida irremovível, posto pelo próprio Rosa, para levar adiante o diálogo e dá um outro passo para aprofundar o que um tal homem vem a significar. Referindo-se a Rosa, ele afirma: "Nasceu no sertão, aquela estepe quase mítica do interior de seu país, encarnada como um mito de consciência brasileira" ${ }^{27}$. Rosa concorda com Lorenz e acrescenta que dois outros elementos importantes devem ser aditados ao ponto de partida, ao homem que nasceu na região que, por assim dizer, encarna o mito da consciência brasileira: ter nascido em Cordisburgo, "o lugar mais formoso, devido ao ar e ao céu, e pelo arranjo que Deus caprichara em seus morros e suas vargens" (RM, 621) e ser mineiro.

Quero retomar esta ideia do sertão como mito da consciência brasileira. De acordo com ela, o sertão, além de ser um local geográfico abrangendo partes de Minas Gerais, Bahia, Goiás, Piauí e Maranhão ${ }^{28}$, é também e, ao que transparece no diálogo entre Rosa e Lorenz, fundamentalmente um "espaço" consciencial. Portanto, nele, posso supor, se manifestam as diversas interpretações engendradas pelas diversas formas assumidas pela consciência brasileira. O sertão é, assim, aquilo em que a consciência brasileira em seus vários tipos se desenvolve, se forma e se configura em várias verdades sobre o que é o Brasil, o planeta e o cosmo. Neste sentido, é lícito presumir que, em um estilo semelhante àquele da FE na qual o que aparece como um caos é apresentado em um ordenamento racionalmente estruturado ${ }^{29}$, o sertão consciencial é também passível de ser ordenado em termos de saberes e verdades de maior ou menor horizonte cognitivo, moral, religioso, etc, de tal forma que ele nos apresenta um painel das formas de manifestação da consciência brasileira desde sua manifestação mais simples até seu estágio formativo de maior amplitude. Esse painel passa a ser, então, uma fenomenologia da consciência brasileira, pois ela tem por tarefa dar razão da racionalidade imanente ao processo de constituição da consciência brasileira. Isto nos conduz à segunda ideia reitora para ler o sertão como espaço consciencial ou, lembrando o vocabulário da FE, experiências da consciência brasileira.

Ad 2): os limites da razão discursiva.

Em outro diálogo, desta vez com Bizzarri, Rosa chama-lhe a atenção para um traço persistente em sua obra e mesmo em sua vida pessoal, de tal

${ }^{27}$ LORENZ, G. Diálogo com Guimarães Rosa, in: Rosa, J. G. Ficção completa, em dois volumes. Rio de Janeiro: Nova Aguiar, 1994, p. 30, (Volume I).

${ }^{28}$ Sobre a relação entre sertão e campos gerais, v. SOARES, C. Corpo de baile: um mundo em transformação, in: Ângulo 115, out./dez., 2008, p. 40-47, p. 42; Pedro Orósio era natural de um "povoadim de vereda, no sertão dos campos-gerais", RM, 620.

${ }^{29}$ Der, dem ersten Blick sich als Chaos darbietende Reichtum der Erscheinungen des Geistes, ist in eine wissenschaftliche Ordnung gebracht; a riqueza do espírito que se apresenta, ao primeiro olhar, como caos é levada a uma ordenação científica (Hegel, Selbstanzeige der Phänomenologie, in: HEGEL, G. W. F. Phänomenologie des Geistes. Neu hrsg. von Hans-Friedrich Wessels u. Heirinch Clairmont. Hamburg: Meiner, 1988, p. 550). 
modo que este traço parece continuar o aprofundamento da autocompreensão rosiana de "homem do sertão". E, de fato, como veremos mais adiante, um traço expresso de forma bastante evidente em RM: "Você já notou, decerto, que, como eu, os meus livros, em essência, são 'anti-intelectualistas' - defendem o altíssimo primado da intuição, da revelação, da inspiração, sobre o bruxolear presunçoso da inteligência reflexiva, da razão, a megera cartesiana" ${ }^{\prime 30}$. Se, portanto, vincularmos as implicações da ideia de sertão consciencial com aquela de níveis de consciência consignada no diálogo de Rosa com Bizzarri, então começa a impor-se um painel consciencial em que a razão discursiva no contexto da cultura brasileira é, para usar um conceito do pensamento hegeliano, suprassumida (aufgehoben), a saber, negada e conservada ${ }^{31}$ no plano consciencial intuitivo: negada, enquanto ela se apresenta, em "seu bruxolear presunçoso", como a explicação última e não mais ultrapassável do real; conservada, já que ela é também um estágio inescapável ao longo do desenvolvimento da consciência brasileira e é também o meio pelo qual o próprio "primado da intuição" é justificado. Ora, "o primado da intuição" sobre "a megera cartesiana" deve, portanto, estar configurado nas experiências da consciência no sertão consciencial. Creio, então, que RM oferece a oportunidade para evidenciar aquele primado.

Em resumo, o enredo de RM descreve uma expedição, formada por cinco indivíduos, que tem lugar em uma região central do sertão de Minas Gerais. Pedro Orósio, "também acudindo por Pedrão Chãbergo ou Pê-Boi" (RM, 617), era o guia da expedição devido ao seu conhecimento do "sertão dos campos-gerais" (RM, 620). Chamava também a atenção por seu "talhe de gigante" (RM, 617). Estava, no entanto, "debaixo de ordem" (RM, 617) daqueles "outros, de bom trato que fossem: mas, pessoas instruídas, gente de mando. E um que vive de seu trabalho braçal não cabe todo avontade junto com esses, por eles pago" (RM, 621). Esses outros constituíam um trio representativo do poder científico, religioso e político-social: "três patrões, entrajados e de limpo aspecto, gente de pessoa" (RM, 617).

Seo Olquiste ou Alquiste, "espigo, alemão-rana, com raro cabelinho barba-de-milho e cara de barata descascada" (RM, 617), é o cientista vindo do exterior, voltado para a pesquisa da fauna, flora e da humanidade da região. Personagem calcada, ao que parece, em cientistas que visitaram o Brasil, como por exemplo, Peter Lund (1801-1880), Seo Alquiste veicula o ponto de vista da razão científica observadora ${ }^{32}$, fazendo uma varredura racional e detalhada da região, "em festa de entusiasmo por tudo, que nem uma criança no brincar" (RM, 621).

\footnotetext{
${ }^{30}$ Citado em ALVES, A. C. T. A viagem em o recado do morro: construção de espaços e identidades, in: Estação Literária, Londrina, Volume 10B, p. 20-32, jan. 2013, p. 22.

${ }^{31}$ Das Aufheben ... ist ein Negieren und ein Aufbewahren zugleich; o suprassumir ... é simultaneamente um negar e um conservar (PhG, 80/FE 113, 96).

${ }^{32}$ Beobachtende Vernunft, razão observadora, capítulo V. A. da FE.
} 
Frei Sinfrão, "frade louro ... desses de sandália sem meia e túnica marrom, que têm casa de convento em Pirapora e Cordisburgo" (RM, 617), é a personificação da cosmovisão predominante no sertão consciencial. Diferentemente do cientista que personifica uma cosmovisão em evidente contraste com a de Pedro Orósio e outras personagens citadas em RM, Frei Sinfrão, cujo traço estrangeiro também transparece em seu modo de falar: "Falava a língua da gente, porém sotaqueava" (RM, 617), encarna uma cosmovisão originalmente estrangeira, mas que conseguiu criar raízes profundas no sertão consciencial a ponto de ser o elemento orientador predominante dos figurados (conceito a ser explicado infra) que povoam o universo de RM. Ilustração disto é a resposta dada por Catraz, uma das personagens que transmite o recado do morro de modo equivocado, ao Frei Sinfrão, quando este último o indaga se ele sabe rezar. Esta resposta é uma espécie de teologia popular sertaneja: “Ah, isso, rezo. Rezo pr'a as almas, toda noite, e de menhã rezo pr'a mim ... Pego com Deus. A gente semos as criaçãozinhas dele, que nem as galinhas e os porcos" (RM, 637). A teologia sertaneja de Catraz, no seu linguajar simples, já marca a unidade entre o homem e a natureza, também tematizada pela mensagem proveniente do morro.

O último membro do trio é o representante político-social: "seo Jujuca do Açude, fazendeiro de gado, e filho de fazendeiro" (RM, 618), oriundo do sertão, mas com "estudos da lida certa de todo plantio de cultura, e das doenças e remédios para o gado, e para os animais ... moço atilado e ambicioneiro" (RM, 621), interessado na expansão de seus negócios tendo em vista o controle político, econômico e social da região.

O trio, portanto, abarca saberes que estão muito além do horizonte cognitivo de Pedro Orósio, mergulhado nos impulsos de seus desejos e pouco afeito à cultura dos patrões: "Do que eles três falavam entre si, do muito que achavam, Pedro Orósio não acertava compreender" (RM, 621). No entanto, tinha o saber do território pelo qual transitavam, pois os campos gerais lhe eram familiares, apesar de seus mistérios. Ele encarna, então, o saber do sertão consciencial na sua face mais dura, concreta, basilar e terrosa. Daí, portanto, a dependência do trio para avançar em um território totalmente desconhecido ou pouco conhecido para ele.

Outro ponto de apoio material do trio aparecia na retaguarda, também a cavalo como também ia o trio, "um Ivo, Ivo de tal, Ivo da Tia Merência ... tangendo os burros cargueiros" (RM, 621). Com Ivo Crônico ou Crônhico e outros dele amigos está armado um conflito, pois Pedro Orósio, ainda não ciente de seu assassinato tramado por eles, despertava-lhes mágoa e ódio em virtude de ser namorador e galanteador, "roubando" deles as mulheres.

Portanto, a configuração da expedição é bastante representativa da organização sócio-político-cultural do Brasil: os poderes científico-religioso-sócio-político sustentados pelos pobres. Todavia, o conflito revelado pela 
mensagem transmitida pelo morro não diz respeito ao conflito entre aqueles poderes e os pobres, mas àquele que tem lugar no interior no mundo dos pobres sertanejos e incide sobre aquilo a que eles, aqueles que vivem de seu trabalho braçal, foram reduzidos pelo jogo daqueles poderes: ele incide sobre as inclinações, impulsos e pulsões de seus corpos físicos, equivalente à sensibilidade (Sinnlichkeit) investigada na FE. Ora, a mensagem revelada pelo morro fará com que Pedro Orósio possa gradualmente elevar-se para além de sua sensibilidade, negando-a e conservando-a, tendo a arte como elemento auxiliar neste movimento de ascensão.

Imediatamente após ser feita a descrição dos membros da expedição, portanto, da configuração físico-espiritual de seus membros, o texto entra em uma espécie de êxtase com a exposição circunstanciada dos mundos mineral, vegetal e animal da região em que eles se movem: "diversa é a região, com belezas, maravilhal" (RM, 621). Ela é encerrada com um tópico que, ao meu ver, orienta as ações de RM, pois o fecho do hino de exaltação à natureza trata da comunicação entre o mundo humano e o mundo natural que só se torna inteligível para aqueles que se encontram em um nível consciencial capaz de entendê-la e, ao mesmo tempo, preanuncia a mensagem a ser transmitida pelo morro e captada por Gorgulho, aquele que está em condições de fazer a mediação entre o mundo moral e o mundo natural: “... o mudo passar alto dos urubus, rodeando, recruzando -; pela guisa esses sabem o que há-de-vir" (RM, 619).

O encontro do grupo dos cinco com Gorgulho ocorre quando a comitiva se encontrava próxima ao morro da Garça, de onde provém o recado que interconecta a natureza e moralidade. Gorgulho é "um velho grimo, esquisito, que morava sozinho dentro de uma lapa, entre barrancos e grotas - uma urubuquara - casa dos urubus, uns lugares com pedreiras" (RM, 623). Diante deste encontro, as reações do trio começam com uma posição inquisitiva de Seo Olquiste, perguntando se ele é "Troglodyt" (RM, 625), passando pela atitude de Frei Sinfrão, oscilando entre a caçoada e a aflição dividida entre, de um lado, de ver algum desgosto no cientista da razão observadora em virtude do encontro com Gorgulho e, de outro, de vê-lo (Seo Olquiste,) "obrar alguma maior inconveniência" (RM, 625), até chegar ao comportamento constrangido de Seo Jujuca, buscando minorar o que ele considerava como as consequências desagradáveis do embaraço de ter encontrado Gorgulho, em sua opinião, um indivíduo simples, rude e bronco, "se dando tanto valor" (RM, 625).

É verdade também que Seo Olquiste oscila entre o espanto e a dúvida sobre aquilo que é dito por Gorgulho: "Hom'êst diz xoiz' imm'portant!", “Chôis' muit' imm'portant?". Com efeito, "se via que algum entendimento, como que de palpite, esteve correndo entre ele [Gorgulho] e o estranjo [seo Olquiste]: porque ele [Gorgulho] ao de leve sorriu, e foi a única vez que mostrou um sorriso, naquele dia. Os dois se miravam" (RM, p. 630). 
Apesar de que aquilo que Gorgulho falava "nem eram coisas do mundo entendível" (RM, p. 630), Gorgulho "achou, como de relance, que seo Alquiste era capaz de pegar o sentido excogitado; e então afiou boca." (RM, p. 630). No entanto, dissuadido por Frei Sinfrão, segundo o qual Gorgulho não dizia nada de importante, secundado por Seo Jujuca, de acordo com o qual o dito por Gorgulho era "do airado" (RM, 630), e cansado do vai-e-vém comunicacional entre ele e Gorgulho, intermediado pelos intérpretes Pedro Orósio, Frei Sinfrão e Seo Jujuca na tradução da fala de Gorgulho "que não auxiliava o se entender - às vezes um engrol fanho, ou baixando em abafado nhenhenhém, mas com partes quase gritadas" (RM, 626), Seo Olquiste, por fim, "desistiu, foi se sentar outra vez no pedaço de pedra" (RM, 631). Em termos de sertão consciencial, há aqui uma aproximação entre a razão discursiva e observadora encarnada no cientista e "um marginal da razão" 33 incorporado em Gorgulho. Isto deixa transparecer, via sorriso de Gorgulho e atenção do cientista ao que falava Gorgulho, uma proximidade entre a razão e seu marginal. O problema, portanto, consiste, de um lado, em absolutizar a reflexividade da razão em detrimento da intuição e, de outra, em fixar-se nesta última e desprezar aquela, lembrando, com isso, em suas linhas gerais, o conflito entre razão (Vernunft) e entendimento (Verstand).

A estranheza da aproximação e do distanciamento entre a razão e o seu além é atenuada, por um lado, justamente por aquele que tanto é o destinatário da mensagem do morro, ouvida por Gorgulho pouco antes do encontro com a expedição, quanto está existencialmente e socialmente próximo a Gorgulho: Pedro Orósio. Por outro lado, a distância consciencial entre Seo Alquiste, em seu canto, e Pedro Orósio e Gorgulho, por seu turno, exige um outro trabalho de mediação, a saber, aquele de Frei Sinfrão e seo Jujuca, já que ambos têm, por assim dizer, um pé no horizonte cultural do cientista e o outro no mundo consciencial de Gorgulho e Pedro Orósio. Com isso, existe um contínuo consciencial que tanto distingue seus nós conscienciais quanto os põe em uma série consciencial evolutiva: desde aqueles que são reduzidos à sua vida pulsional (Pedro Orósio e Ivo) - embora dotados de razão e, portanto, passíveis de elevação espiritual, e inclusive, para além da razão, como mostra o processo de formação de Pedro Orósio -, passando pela própria razão (o trio formado por seo Olquiste, Frei Sinfrão e seo Jujuca) até alcançar o marginal da razão (Gorgulho). Como que também intuindo quem tentaria levar a cabo o que foi revelado pelo recado do morro da Garça, Gorgulho lança "um olhar de grandes raivas" contra Ivo, aquele "que no meio daquilo era o sempréstimo, glosou qualquer tolice" (RM, 630).

${ }^{33}$ ALVES, A. C. T. A viagem em o recado do morro: construção de espaços e identidades, in: Estação Literária, Londrina, Volume 10B, p. 20-32, jan. 2013, p. 31. 
Persuadido por Pedro Orósio, de quem Gorgulho gostava e era dele amigo (RM, 626), Gorgulho se junta ao grupo durante uma parte da caminhada até que os caminhos se dividem em razão dos objetivos da expedição e de Gorgulho, depois de ter comunicado ao grupo o recado do morro da Garça: "Morte à traição, foi que ele Morro disse. Com a caveira, de noite, feito História Sagrada, del-rei, del-rei!" (RM, 630). "Morte à traição" se referia à emboscada preparada por Ivo e seus colegas para matar Pedro Orósio.

Na conversa com os membros da expedição, curiosos sobre os hábitos dos urubus, Gorgulho procura explicar a vizinhança casual com os urubus: "Eu sou velho daqui, bruaca velha daqui. A fui morar lá, mó de me governar sozinho. Tenho nada com urubu, não. Assituamento deles" (RM, 629). Sua intenção fundamental, portanto, era desvencilhar-se de uma heteronomia e, ao invés, expressar sua autonomia. Esta, no entanto, lhe aproximou da natureza a tal ponto que ele se tornou disponível para apreender sua inteligibilidade, o mundo entendível da natureza, e, com isso, mediante sua autonomia praticada, ser um pontífice entre o moral e o natural. Ao recusar a convencionalidade da sociedade humana e retirar-se para uma urubuquara, ele se coloca em posição privilegiada para mediar as transações entre o humano e o natural. Portanto, seu afastamento da sociedade, a convivência com os urubus, aqueles que "sabem o que há-de-vir", e com o "maravilhal" da natureza são sua formação ( $\pi \alpha \iota \delta \varepsilon i ́ \alpha$, Bildung) para entender tanto a natureza quanto o mundo humano.

No momento em que encontra o grupo dos cinco, ele estava a caminho de ter com seu irmão, o Catraz, para dissuadi-lo de sua intenção de casar. Seu propósito de afastar-se das convenções sociais e também de convencer outros sobre o que ele considera correto não pode ser qualificado como atos de um doido (RM, 626), como, a princípio, interpreta seo Jujuca e outros tantos que interpretam este texto rosiano. Isto é refutado pelo próprio Pedro Orósio, expressando sua confiança na seriedade da pessoa de Gorgulho e como que intuindo a verdade do que ele, Gorgulho, comunicava ao grupo expedicionário. Não perdendo "o bom-uso de qualquer sociedade" (RM, 626), Gorgulho parece representar a recusa de um destino, aquele reservado a Pedro Orósio, Ivo e tantos outros, socialmente a ele semelhantes, retratados em RM: viver sob o governo de gente instruída e de mando. Mas um governo não só material, mas também consciencial. Portanto, o poder do negativo exercido por Gorgulho em seu ato de autogoverno torna-se a condição para captação da mensagem do morro da Garça.

Quando a comitiva e Gorgulho dividem-se em seus caminhos, RM passa a retratar dois mundos paralelos que se encontram no final: a trajetória da expedição e a do recado. Nas palavras de Rosa, a revelação do morro é recebida "por um marginal da razão [Gorgulho], e veiculada e aumen- 
tada por outros seres não-reflexivos, não escravos ainda do intelecto: um menino [Joãozezim], dois fracos de mente [Catraz, irmão de Gorgulho, e Guégue], dois alucinados [Nomimedômine e o Coletor] - e, enfim, por um ARTISTA [Laudelim], que, na síntese artística, plasma-a em canção, do mesmo modo perfazendo, plena, a revelação inicial". Portanto, somente com a tradução da mensagem em canção por Laudelim, após ser constantemente desfigurada por seres não afeitos à reflexão racional, típica do trio formado por seo Alquiste, Frei Sinfrão e seo Jujuca, o destinatário da mensagem, Pedro Orósio, consegue compreendê-la e afasta a morte à traição planejada por Ivo e seus amigos. Com isso, finalmente, o mundo humano e o mundo natural, moralidade e felicidade alcançam sua reconciliação (Versöhnung) e o "maravilhal" da natureza se harmoniza com o mundo humano que, ao fim, captou sua mensagem.

Pedro Orósio, no entanto, acolhe e entende a mensagem não só pela mediação do artista Laudelim, mas também porque ele mesmo percorre sua formação consciencial, avança para além de suas paixões, atualiza uma percepção intuitiva (sempre disponível, mas até então abafada) que se derrama em razão demonstrativa. A canção de Laudelim falava da morte do Rei por sete cavaleiros, à traição. Pedro Orósio, então, raciocina e intui, intui e raciocina: "Parecia coisa que tinha estado escutando aquilo a vida toda! Palpitava o errado. Traição? Ah, estava entendendo. Num pingo dum instante. Olhou aqueles, em redor. Sete? Pois não eram sete? ... e puxou no Ivo um bofetão, com muito açoite" (RM, 665). Os sete em redor eram compostos por Ivo e seus colegas, cujos nomes representam forças cósmicas, corpos celestes: Ivo Crônhico (Cronos/Urano) Jovelino (Júpiter), Martinho (Marte), João Lualino (Lua), Zé Azougue (Mercúrio), Veneriano (Vênus), Hélio Dias Nemes (Sol), os quais, rodeando Pedro Orósio, se puseram em posição para matá-lo. Diante deste quadro, o morro da Garça, “... posto lá, a nordeste, testemunho. Belo como uma palavra" (RM, 626), enraízado no solo, como ele, Pedro Orósio, Pedro Montanha (ö@os, óros, montanha), oráculo terreno que transmite uma mensagem sobre um conflito que parece ir além do que é simplesmente humano e terráqueo.

Sete foram as estações pelas quais navegou o recado do morro, sete aqueles que planejaram a morte de Pedro Orósio e também sete foram os estágios, as fazendas, do trajeto percorrido pela expedição: Apolinário (Sol), Nhá Selena (Lua), Marciano (Marte), Nhô Hermes (Mercúrio), Jove (Júpiter), Dona Vininha (Vênus) e Juca Saturnino (Saturno). Eles parecem também evocar uma trajetória cósmica, de tal modo que a formação de Pedro Orósio, assim como aquela de Gorgulho, permite uma integração do homem com a natureza, mas uma que vai além da terra e se expande pelo universo. $\mathrm{O}$ recado do morro é, assim, bem mais que uma mensagem sobre um conflito entre humanos, mas ele revela um conflito cósmico que se singulariza na terra na forma de uma tentativa malsucedida de assassinato. 


\section{O silogismo dialético de RM}

Assim como a FE é compreendida mediante um silogismo dialético, assim também o sertão consciencial em RM. Evidentemente, não se trata de simplesmente "aplicar" a forma do silogismo dialético ao conteúdo de RM. Em primeiro lugar, isto é rejeitado pelo próprio Hegel, pois ele mesmo considera errada a compreensão do aparato dialético através da metáfora do instrumento (Werkzeug, FE 73, 71/PhG, 57) e isto já registrado no âmbito da FE, mas também reafirmado na Ciência da Lógica ${ }^{34}$. Em segundo lugar, como os conteúdos de FE e RM são distintos no que diz respeito às especificidades das formas de consciências que se apresentam em FE e RM, aquela aplicação estaria interditada de saída. Todavia, o que pretendo fazer é reelaborar os conceitos dialéticos empregados por Hegel - especificamente, no caso em questão, os conceitos de silogismo e figura, já tratados acima ao falar das experiências da consciência na FE -, de tal modo que eles, agora readaptados e ajustados ao texto de $\mathrm{RM}$, possam demonstrar a racionalidade do movimento da consciência no âmbito de RM.

Em primeiro lugar, trato dos conceitos de figura e figurado. Figurado é a palavra usada por Nominedômine, o eremita que prega o fim do mundo ("Quer ver o fim do mundo? Que vem vindo redondando aí, rodando feito pé-d'água, de temporal e raios", RM, 643), por ocasião de seu encontro com Pedro Orósio e Guégue, em seu esforço para identificá-los: "vocês dois são criaturas, ou são figurados do Inimigo?! Então me sigam no sinal sagrado! - e traçou em testa e boca e peito o da Cruz. Pedro Orósio e o Guégue o imitaram, com o que ele pareceu se abrandar" (RM, 642).

De modo semelhante ao conceito de figura na FE, o conceito de figurado em RM traduz uma específica relação entre saber e verdade. Assim sendo, cada figurado tem seu próprio saber e sua própria verdade, constituindo, com isso, um horizonte cognitivo que permite acessar certos objetos e também desconhecer outros. Figurado, por conseguinte, diz respeito à menor ou maior capacidade de captar a mensagem proveniente do morro do Garça, de acordo com o saber e a verdade de cada figurado.

Duas ilustrações de o que vem a ser figurado são Gorgulho e Nominedômine. Com efeito, esses dois figurados também elucidam uma confusão muito frequente. Como os dois figurados se afastam da racionalidade incorporada no trio da ciência, religião e política/economia, a tendência é

\footnotetext{
${ }^{34} \mathrm{O}$ método dialético lida com a "marcha da coisa mesma" (Gang der Sache selbst), sem aplicar à coisa mesma, a saber, ao objeto de investigação um repertório conceitual que lhe é estranho, HEGEL, G. W. F. Wissenschaft der Logik. Frankfurt: Suhrkamp, 1973, p. 50. (Werke, 5; Theorie-Werkausgabe).
} 
igualá-los, classificando-os como doidos, alucinados ou fracos da mente, nivelando figurados totalmente diferentes ${ }^{35}$.

Gorgulho expressa saber e verdade que traduzem um horizonte cognitivo mais amplo do que aquele horizonte vislumbrado pela racionalidade incorporada no trio, ao passo que saber e verdade comunicados pelo Nominedômine veiculam uma alucinação ou uma desarmonia entre o divino e humano, aquela que engendra o evento do fim do mundo. E essa desarmonia se torna mais evidente quando ele introduz em sua mensagem de fim de mundo o recado transmitido pelo morro que chegou até ele via Guégue de uma forma bastante desfigurada. Portanto, o recado do morro captado por Gorgulho e a mensagem de fim de mundo transmitida por Nominedômine são bastante diferentes, mesmo que este último incorpore o recado do morro em sua pregação de fim de mundo. Por conseguinte, o que é pós-racional, o recado do morro, é falsamente identificado com o pré-racional, a mensagem de Nominedômine sobre o fim do mundo. Enquanto este último prega uma desarmonia entre o humano, moral e terreno, de um lado, e o divino, natural e cósmico, de outro, cujo desfecho é o assim chamado fim do mundo, já que a harmonia entre eles se tornou inviável, Gorgulho é o médium de uma mensagem que apregoa a harmonia que, ao final, se tornará efetiva. Se os três patrões consideram impossível tal harmonia, em virtude de que o mundo humano e o mundo natural são ordens de ser completamente heterogêneas, bem ao estilo da visão moral do mundo que parte de uma cisão originária; se o alucinado Nominedômine também considera inviável tal harmonia, mas responsibiliza o ser humano por essa deficiência, de tal forma que a sanção divina vai cobrar este erro dos humanos, a mensagem captada por Gorgulho e efetivada por Pedro Orósio demonstra os saberes equivocados dos racionais presunçosos e pré-racionais alucinados.

Neste sentido, a mensagem efetivada por Pedro Orósio se assemelha à atitude dos estoicos e epicuritas que, aos olhos de Kant, queriam efetivar o sumo Bem sem o auxílio divino, sem o postulado da existência de Deus, com o "mero uso das forças naturais" 36 . Por isso, Kant louva a ideia cristã de Reino de Deus (Reich Gottes), a tradução religiosa do conceito filosófico de sumo Bem, já que ela apregoava a necessária intervenção de Deus para que o ser humano dele participasse ${ }^{37}$, já que "natureza e moral" ("Natur und Sitten"), sendo cada uma estranha e alheia (fremd) uma à outra, só podem ser harmonizadas por "um autor santo"38. Do lado oposto a Kant, apesar

\footnotetext{
${ }^{35}$ Aqui temos uma ilustração daquilo que é chamado falácia pré/trans, vide. WILBER, K. The eye of spirit, in: WILBER, K. The collected works of Ken Wilber. Boston: Shambhala, 2020, p. 467 e 558. (Volume Seven).

${ }^{36}$... bloßen Gebrauch der natürlichen Kräfte ..., KANT, I. Kritik der praktischen Vernunft. Darmstadt: WBG, 1983, Anmerkung, A 230.

${ }^{37}$ KANT, I. Kritik der praktischen Vernunft. Darmstadt: WBG, 1983, A 229-234.

${ }^{38}$ KANT, I. Kritik der praktischen Vernunft. Darmstadt: WBG, 1983, A 232.
} 
de suas diferenças, estoicos, epicuristas, Hegel (ainda que de forma não plenamente desenvolvida na FE, mas evidente na exposição das manobras dissimuladoras da consciência moral, certa de si mesma) e Rosa pensam que o ser humano, em virtude de suas próprias forças, é capaz de levar a cabo aquela harmonia. Por conseguinte, a arte toma o lugar reservado a Deus por Kant no esforço de unir o moral e o natural. Isto, no entanto, não pode afastar o fato de que o médium Gorgulho, ainda bastante envolvido pela cosmovisão cristã, acolhe a mensagem procedente do morro, com as dificuldades que são próprias a alguém posicionado de um forma bastante vantajosa para lidar com ela, ainda que os dois figurados mais envolvidos com a religião, Frei Sinfrão e Nominedômine, não estejam à altura de interpretar adequadamente o recado. Relatando à comitiva o que foi comunicado pelo morro da Garça, Gorgulho "falava: - Que que disse? Del-rei, ô, demo! Má-hora, esse Morro, ásparo, só se é de satanáz, ho! Pois-olhe-que, vir gritar recado assim, que ninguém não pediu: é de tremer as peles...Por mim, não encomendei aviso, nem quero ser favoroso...Del-rei, del-rei, que eu cá é que não arrecebo dessas conversas, pelo similhante! Destino, quem marca é Deus, seus Apóstolos!" (RM, 630). Por isso mesmo, torna-se mais relevante o papel da arte para tanto acolher a mensagem, ainda captada com os prejuízos conscienciais de Gorgulho, mas acolhida por Pedro Orósio sem aqueles prejuízos, quanto para decifrá-la, interpretada, de maneira equivocada, por Joãozezim, Catraz, Guégue, Nomimedômine e o Coletor, mas, por fim, reconfigurada em seu sentido original pelo artista Laudelim.

Diferentemente do conceito de figura na FE, no entanto, os figurados em RM não estão entrelaçados em uma sequência tal que o figurado subsequente é o resultado necessário do questionamento ao saber e à verdade do figurado imediatamente anterior. Se a figura da percepção é o resultado necessário da experiência da consciência na figura imediatamente anterior da certeza sensível, a descrição dos cinco membros da expedição, com a qual RM tem início, não obedece ao encadeamento lógico necessário de um figurado necessariamente sucedendo a um outro. No caso de RM, de modo diverso, há uma espécie de painel apresentando os vários figurados e seus respectivos horizontes cognitivos, sem que, por exemplo, o figurado Seo Alquiste seja o resultado necessário do figurado imediatamente anterior, Pedro Orósio. No entanto, figura e figurados podem ser ordenados de acordo com uma hierarquia de maior ou menor amplitude cognitiva. Em RM, em sua escala descendente de horizontes cognitivos para compreender o recado do morro, há a seguinte ordenação dos figurados: Gorgulho, Laudelim e Pedro Orósio, os membros da comitiva (seo Olquiste, Frei Sinfrão e seo Jujuca do açude), Ivo e seus companheiros, os fracos de mente (Catraz, irmão de Gorgulho, e Guégue), e os dois alucinados (Nomimedômine e o Coletor). Considerando as atividades praticadas pelos figurados, a arte se encontra acima daquelas praticadas pelos três patrões: ciência, religião e política/economia. 
Outros personagens citados em RM devem ser enquadrados ao longo desse espectro do sertão consciencial, principalmente aqueles que formam a maioria da população do sertão: "a pobreza de muitos, tanta míngua, tantos trabalhos e dificuldades. Até lhe [a Pedro Orósio] deu certa vontade de não ver, de sair dali sem tardança" (RM, 634). Creio, pois, que alguns poucos destes pobres podem alcançar o horizonte cognitivo de Gorgulho. No entanto, o aferrar-se dos três patrões aos seus horizontes cognitivos é um grande obstáculo para aceder à verdade comunicada pelo morro.

Em segundo lugar, o silogismo dialético de RM pode ser assim apresentado:

Universalidade: a unidade dialética entre espírito e natureza, mundo moral e mundo natural, terra e cosmo: a verdade comunicada pelo morro.

Particularidade: estações (as fazendas) percorridas pela comitiva e o arraial e seus arredores em que Pedro Orósio termina seu trabalho com a comitiva e derrota Ivo e seus companheiros.

Singularidade: figurados da consciência.

A universalidade deste silogismo dialético é constituída pela unidade dialética entre o espírito, mundo moral e terra, de um lado, e a natureza, mundo natural e cosmo, de outro. A unidade dialética significa identidade e diferença, de tal modo que a diferença entre a natureza e o espírito humano constatada, por exemplo, pela racionalidade dos três patrões não é a percepção da realidade originária, a qual, no entanto, é a condição de possibilidade do recado do morro e sua comunicabilidade. Porém, a essa realidade originária tem acesso imediato o figurado Gorgulho em virtude de seu modo de vida, ao passo que Pedro Orósio acessa tal verdade através de várias mediações. Caso houvesse uma cisão (Entzweiung) originária entre o mundo humano e o mundo natural, haveria um abismo intransponível entre eles e, portanto, o recado do morro da Garça nunca seria transmitido para Gorgulho e este nunca captaria o recado, mesmo que houvesse da parte dele uma disposição consciencial para acolhê-la. Portanto, esta disposição está harmonizada com a natureza, ou em termos hegelianos, o figurado Gorgulho e o recado do morro da Garça, o moral e o natural são diferenciações internas da totalidade dialética.

O destinatário da mensagem do morro da Garça não é capaz de captá-la imediatamente. De modo semelhante às experiências da consciência na FE, nas quais gradativamente o fenômeno (Erscheinung) e a essência (Wesen, FE 89, 82/PhG, 68) se reconciliam, Pedro Orósio acede à verdade do recado do morro ao longo de um processo de formação cristalizado nas sete fazendas, seus sentidos cósmicos e o arraial (as figurações de RM), em cujos arredores é desbaratada a execução do plano de assassinato de Pedro Orósio. Todavia, diferentemente das figurações do silogismo dialético da $\mathrm{FE}$, o momento da particularidade, que são momentos meramente lógicos 
de organização dialética da experiência da consciência, em RM tem lugar também no tempo e espaço. Através das estações registradas no momento da particularidade em RM ou dos intervalos entre elas, o recado do morro é tanto desconfigurado, transfigurado e reconfigurado pelos figurados quanto Pedro Orósio paulatinamente realiza a suprassunção (Aufhebung) dialética de sua sensibilidade, sua vida pulsional, e efetivamente capta o recado do morro. Pedro Orósio, portanto, realinha seus planos conscienciais (ilustrados pelas figurados Gorgulho, os três patrões, Laudelim e o seu próprio plano inicial de jornada, a esfera dos impulsos e inclinações) e acede àquela verdade inicialmente apreendida somente por Gorgulho. Ao invés de uma apreensão imediata e direta da verdade transmitida pelo morro da Garça por parte de Gorgulho, em modo análogo à pretensão da certeza sensível de também ser uma apreensão direta e imediata da verdade, embora, em ambos casos, o caráter puramente, exclusivamente imediato da verdade seja negado (no caso de Gorgulho, isto é demonstrado pela mediação cristã do acolhimento da verdade comunicada pelo morro da Garça), o recado do morro é captado no transcurso de um longo processo de mediação, também análogo ao movimento da consciência na FE.

A singularidade representa os figurados em sua distribuição espacial e temporal, assim como também é o caso na FE. Por conseguinte, eles expressam formas determinadas de saber para captar a verdade revelada pelo morro. Constantemente variada ao longo da recepção da mensagem pelos figurados, assim como também é sempre revista a verdade do espírito ao longo das figuras da consciência na $\mathrm{FE}$, a verdade do recado do morro é, por fim, reconfigurada na forma de uma canção e, portanto, tornada acessível ao figurado Pedro Orósio, assim como na FE, de modo análogo, o saber absoluto é a figura singularizada em que o espírito na sua universalidade e particularidade apreende o que ele é.

Creio que é lícito aqui lembrar o papel do Belo apontado por Gadamer, pois esse papel ilustra muito bem o papel da arte no universo consciencial brasileiro, segundo Rosa: "a função ontológica do Belo é transpor o abismo entre o ideal e o efetivo" ${ }^{39}$. Ora, a canção de Laudelim proporciona a mediação reconciliadora entre o ideal (representado pela unidade dialética da universalidade em RM: a verdade do morro) e o real (os momentos da particularidade e singularidade em RM, nos quais a verdade do morro se realiza). Assim sendo, RM afirma que o que é ideal é efetivo e o que é efetivo é ideal, pelo menos para quem sabe ver tanto o ideal quanto o real. Por conseguinte, de modo análogo ao movimento da percepção da verdade por parte da consciência fenomenológica que gradativamente

\footnotetext{
39 "Es ist die ontologische Funktion des Schönen, den Abgrund zwischen dem Idealen und dem Wirklichen zu schließen"; GADAMER, H.-G. Die Aktualität des Schönen. Kunst als Spiel, Symbol und Fest. Stuttgart: Reclam, 2020, p. 20. A rigor, schließen significar, neste contexto, fechar, mas creio que a melhor versão para o português, neste caso, é transpor.
} 
alcança a percepção da verdade que nós, o público leitor das experiências dessa consciência na FE, já possuímos desde o início dessa experiência, assim também Pedro Orósio obtém a percepção da verdade, anunciada inicialmente por Gorgulho, e que nós, leitores e leitoras de RM, já temos também desde o início. Isto resulta, então, na felicidade de Pedro Orósio, tornada possível pela intervenção do recado do morro que impede a imoralidade de seu assassinato.

Gadamer faz referência ao Fedro de Platão (428/427-348/347 a.C.), em que é relatado o mito de que as almas humanas, juntamente com os deuses, viajam, a partir da terra, para "o local supraceleste" 40 e contemplam "o divino, o belo, o sábio, o bem e tudo aquilo que é assemelhado a isto" ${ }^{41}$. Todavia, as almas humanas são incapazes de manter a contemplação, como o fazem os deuses, pois estes não possuem as deficiências da alma humana. Com isso, elas, por assim dizer, perdem suas asas e caem de volta na terra. Justamente neste momento, aponta Gadamer, entra em cena o papel exercido pela arte: "graças ao Belo, logra-se, com o passar do tempo, recordar-se do mundo verdadeiro. Isto é o caminho da filosofia" ${ }^{42}$. Ora, como vimos acima, o percurso de Pedro Orósio e os nomes de seus adversários fazem alusão a um contexto cósmico, sem falar no fato de que, diante destas alusões ao contexto cósmico, o morro da Garça possa ser uma mediação terrena entre o terráqueo e o cósmico. Diante deste quadro delineado pela interpretação de Gadamer do Fedro e do que é descrito em RM, a arte, então, proporciona a (ao "filósofo") Pedro Orósio recordar-se do que ele já sabia: "Parecia coisa que tinha estado escutando aquilo a vida toda!".

Este papel de mediação entre o ideal e o real é também a função do próprio texto de RM. Enquanto obra de arte, ele exerce um papel de mediação entre o ideal e o real, alertando para necessidade da mediação entre a razão e o seu marginal. RM, como obra de arte, desempenha um papel semelhante àquele da lógica do para nós (für uns, PhG, 68 /FE87, 81) na FE. Ele, portanto, apreende o movimento e o devir (Bewegund und Werden) das diversas formas de consciência nas quais o ideal se torna efetivo e o efetivo se torna ideal. De certa forma, o papel desempenhado por Laudelim no "caso de vida e de morte, extraordinariamente comum, que se passou com o enxadeiro Pedro Orósio" (RM, 617) é análogo àquele que desempenha RM como obra de arte no contexto da cultura brasileira

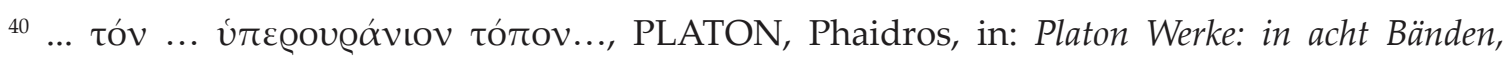
Griechisch und Deutsch. Hrsg von Gunther Eigler. Darmastadt: WBG, 1990, 247 c.

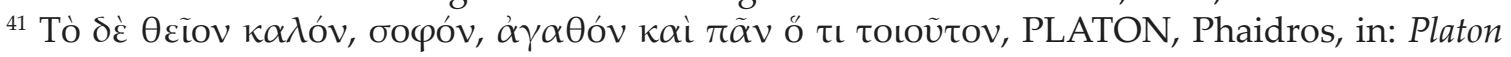
Werke: in acht Bänden, Griechisch und Deutsch. Hrsg von Gunther Eigler. Darmastadt: WBG, 1990, 246 d-e.

${ }^{42}$ Dank dem Schönem gelingt es auf die Dauer, sich an die wahre Welt wiederzuerrinern. Das ist der Weg der Philosophie, GADAMER, H.-G. Die Aktualität des Schönen. Kunst als Spiel, Symbol und Fest. Stuttgart: Reclam, 2020, p. 19. 
como um todo. O texto de RM é, assim, uma obra de arte que tenta transpor o abismo que separa a intuição e a inteligência reflexiva, a anamnese daquilo que desde sempre já é conhecido, mas ainda não reconhecido. Ao fazer isto, o trabalho artístico de Rosa expresso em RM parece expor o que é um marco inamovível da consciência brasileira: levar a cabo aquela mediação com a ajuda da arte.

\section{Bibliografia}

ALVES, A. C. T. A viagem em o Recado do Morro: construção de espaços e identidades, in: Estação Literária, Londrina, Volume 10B, p. 20-32, jan. 2013.

GADAMER, H.-G. Die Aktualität des Schönen. Kunst als Spiel, Symbol und Fest. Stuttgart: Reclam, 2020.

GOMES. G. Os Dois Conceitos Freudianos de Trieb, in: Psicologia: Teoria e Pesquisa. Set-Dez 2001, Vol. 17 n. 3, p. 249-255.

HEGEL, G. W. F. Phänomenologie des Geistes. Neu hrsg. von Hans-Friedrich Wessels u. Heirinch Clairmont. Hamburg: Meiner, 1988.

- Fenomenologia do Espírito. Tradução de Paulo Menezes com a colaboração de Karl-Heinz Efken e José Nogueira Machado. 2a. Edição. Petrópolis: Vozes, Bragança Paulistas, Universidade São Francisco, 2003. (Volume único).

5; Theorie-Werkausgabe).

. Wissenschaft der Logik. Frankfurt: Suhrkamp, 1973, p. 50. (Werke,

Grundlinien der Philosophie des Rechts oder Naturrecht und Staatswissenschaft im Grundrisse. Frankfurt: Suhrkamp, 1973, p. 24. (Werke, 7; Theorie-Werkausgabe).

. Selbstanzeige der Phänomenologie, in: HEGEL, G. W. F. Phänomenologie des Geistes. Neu hrsg. von Hans-Friedrich Wessels u. Heirinch Clairmont. Hamburg: Meiner, 1988, p. 550.

JOÃO GUIMARÃES ROSA. Banco de Dados Bibliográfico (https://www.usp.br/ bibliografia/index.php?s=grosa), visitado em 15 de janeiro de 2021.

KANT, I. Kritik der praktischen Vernunft. Darmstadt: WBG, 1983.

LORENZ, G. Diálogo com Guimarães Rosa, in: Rosa, J. G. Ficção completa, em dois volumes. Rio de Janeiro: Nova Aguiar, 1994. p. 30, (Volume I).

PLATON. Phaidros, in: Platon Werke: in acht Bänden, Griechisch und Deutsch. Hrsg von Gunther Eigler. Darmastadt: WBG, 1990.

ROSA, J. G. O recado do morro, in: Rosa, J. G. Ficção completa, em dois volumes. Rio de Janeiro: Nova Aguiar, 1994. p. 615-66, (Volume I).

. No Urubuquaquá, no Pinhém. 9. Ed. Rio de Janeiro: Nova Fronteira, 2001. (Edição eletrônica). 
SOARES, C. Corpo de baile: um mundo em transformação, in: Ângulo 115, out./ dez., 2008, p. 40-47, p. 42.

VAZ, H. L. Análise do texto da Fenomenologia do Espírito de G. W. F. HEGEL. A Moralidadade, $3^{a}$ Parte da seção Espírito (Cap. VI). Ficha 284, pertencente ao Memorial Padre Vaz da biblioteca da Faculdade Jesuíta de Filosofia e Teologia do Centro de Estudos Superiores da Companhia de Jesus, Belo Horizonte, Brasil, catalogado como 20914538 e localização AP 187.311 VAZ ANA.

VIEIRA, L. A. Kant e Hegel sobre moralidade e felicidade. In: BOMBASSARO, L. C. \& DAlBOSCO, C. A. \& HERMANN, N.. (Org.). Percursos hermenêuticos e politicos: Homenagem a Hans-Georg Flickinger. 1a.ed.Porto Alegre: EDIPUCRS, 2014, v. 1, p. 289-315; 7 .

. A visão moral do mundo. In: VIEIRA, Leonardo A.; SILVA, Manuel M. (Org.). Interpretações da Fenomenologia do Espírito de Hegel. 1ed.São Paulo: Loyola, 2014, v. 1, p. 347-355.

. A dissimulação. In: VIEIRA, Leonardo A.; SILVA, Manuel M. (Org.). Interpretações da Fenomenologia do Espírito de Hegel. 1ed.Loyola: São Paulo, 2014, v. 1 , p. 355-367.

WILBER, K. The eye of spirit, in: WILBER, K. The collected works of Ken Wilber. Boston: Shambhala, 2020, p. 467 e 558. (Volume Seven).

Enderço do Autor:

Rua Antônio Aleixo, 353 - Apto. 1004

Bairro Lourdes

30180-150 Belo Horizonte - MG

leonarva@yahoo.com 